УДК 342.9

DOI https://doi.org/10.32849/2663-5313/2019.9.21

\title{
Тарас Савченко,
}

здобувач Донецького юридичного інституту

Міністерства внутрішніх справ Украйни

\section{АДМІНІСТРАТИВНО-ПРАВОВЕ РЕГУЛЮВАННЯ ГАЛУЗІ МИСЛИВСЬКОГО ГОСПОДАРСТВА ТА ПОЛЮВАННЯ}

У статті досліджено адміністративно-правове регулювання в галузі мисливського господарства та полювання. Запропонований авторський підхід до класифікаиї̈ приниипів та функиій адміністра тивно-правового регулювання в досліджуваній галузі. Наголошено на доцільності виділення таких приниипів иінової політики і иіноутворення в мисливському господарстві: 1) приниип спрямування цінової політики на досягнення максимальної величини економічного, екологічного та соціального ефектів від ведення мисливського господарства; 2) приниип гнучкості иінової політики і иіноутворення в мисливському господарстві; 3) приниип державної підтримки формування иінової політики в мисливському господарстві; 4) приниип пріоритетності стимулюючої функиії ціни; 5) приниип урахування в ціні екологічних витрат. Визначено, що головним напрямом діяльності держави в нових сучасних умовах стає створення сприятливих правових і економічних умов для перетворень у різних сферах, у тому числі й у сфері земельних відносин, що й позначається терміном «державне регулювання», що, на відміну від управління, передбачає дещо іншу стратегію - не надання впливу для забезпечення виконання певних рішень, а створення належних умов для ефективного функиіонування відповідної сфери. Зроблено висновок, що забезпечення охорони навколишнього природного середовища та сприяння сталому природокористуванню стають одними із головних функиій держави. Основу правового регулювання будь-якої сфери людської діяльності становлять правові принципи - основні засади побудови самої системи адміністративно-правового регулювання тієї чи іншої сфери. Розроблення, юридичне закріплення та чітке виконання й дотримання приниипів правового регулювання мисливського господарства та полювання є запорукою сталості, ефективності та раиіональності досліджуваного виду природокористування. Впровадження приниипів адміністративно-правового регулювання в галузі мисливського господарства та полювання сприятиме організачії та розвитку вказаних галузей, а їх дотримання позитивно впливатиме на відтворення та використання мисливських угідь та послуг (продукиії) мисливського господарства та полювання, збереження різноманіття тваринного світу в межах мисливських угідь на території України.

Ключові слова: мисливство, полювання, мисливське господарство, принципи функції, адміністративно-правове регулювання, державне управління.

Актуальність теми. Одним із найдавніших видів використання тваринного світу сміло можна назвати полювання. Незважаючи на те, що полювання вже давно набуло спортивного характеру, стало своєрідним видом відпочинку, воно й досі залишається одним із видів діяльності, що спрямована на отримання засобів існування та товарної продукції мисливського господарства.

Слід зазначити, що наразі ані чинне законодавство, ані сучасна наукова література не дають чіткого та вичерпного визначення поняття адміністративно-правового регулювання в галузі мисливського господарства та полювання. Немає і єдиного розуміння принципів і функцій, що визначають зміст управлінської діяльності держави у сфері ведення мисливського господарства та полювання.
Створення адекватної системи адміністративно-правового регулювання в галузі мисливського господарства та полювання є надійним способом забезпечення реалізації поставлених державою цілей і завдань у даній сфері, однією 3 необхідних передумов досягнення економічної та соціальної стабільності в державі.

Мета роботи - виокремити та дослідити принципи адміністративно-правового регулювання в галузі мисливського господарства та полювання, визначити загальні та спеціальні функції адміністративно-правового регулювання в цій сфері.

Питанням, пов'язаним з аналізом принципів адміністративно-правового регулювання мисливського господарства та полювання присвячена незначна кількість праць вітчизняних вчених, проте серед них слід 
виокремити праці О. Томина, Н. Березіну, I. Гуля, Р. Данилюк, В. Овдієнко, І. Дробот. Водночас види та зміст функцій адміністративно-правового регулювання в галузі мисливського господарства та полювання досі не були предметом дослідження науковців.

Виклад основного матеріалу. Дослідження принципів та функцій адміністративно-правового регулювання в галуз мисливського господарства та полювання, на наш погляд, варто розпочати 3 поняття та юридичної природи адміністративноправового регулювання та лише після цього перейти до дослідження особливостей та різновидів самих принципів та функцій адміністративно-правового регулювання у цій сфері.

Для розкриття змісту поняття «адміністративно-правове регулювання» звернімось до значення самого терміна «регулювання» (від лат. regulo - правило). У Великому тлумачному словнику сучасної української мови дається таке визначення слова «регулювати»: впорядковувати що-небудь, керувати чимось, підкоряти його відповідним правилам, певній системі; домагатись нормальної роботи машини, установки, механізму i т. ін., забезпечуючи злагоджену взаємодію складових частин, деталей, зменшуючи або збільшуючи швидкість, величину і т. ін., досягати потрібної сили, належного ступеня вияву чого-небудь $[1$, с. 1204]. Визначення регулювання в правовій сфері можна прочитати в низці юридичних та наукових праць: зокрема, під регулюванням розуміється: 1) різновид правового впливу, що передбачає використання спеціальних правових засобів у зв'язку з необхідністю юридичної організації суспільних відносин [2, с. 54]; 2) правовий організаційний вплив на суспільні відносини, який здійснюється з метою підтримання чинного режиму функціонування системи без іï̈ переходу в новий стан і полягає в забезпеченні упорядкованості суспільних відносин [3, с. 84-85]; 3) різноманітні форми юридичного впливу держави на поведінку суб'єктів суспільних відносин [4, с. 26].

Щодо визначення терміна «адміністративно-правове регулювання», то аналіз спеціальної літератури показав відсутність єдиного підходу до його розуміння юристами та науковцями. Так, В.В. Галунько та O.М. Єщук, досліджуючи поняття та зміст адміністративно-правового регулювання, визначають останнє як цілеспрямований вплив норм адміністративного права на суспільні відносини з метою забезпечення за допомогою адміністративно-правових засобів прав, свобод і публічних законних інтересів фізичних та юридичних осіб, нор- мального функціонування громадянського суспільства та держави [5]

I.M. Шопіна розуміє адміністративноправове регулювання як адміністративноправовий вплив на суспільні відносини, який здійснюється за допомогою комплексу адміністративно-правових засобів та інших правових явищ, які в сукупності становлять механізм адміністративно-правового регулювання [6, с. 55].

Зовсім інший підхід до визначення адміністративного правового регулювання наявний у відповідному визначенні П.С. Пацурківського. Так, під адміністративно-правовим регулюванням науковець розуміє спосіб пізнання права, при якому право розглядається як процес, пов'язаний з формуванням права та його реалізацією у фактичних вчинках $[7$, c. 16$]$

Межі адміністративно-правового регулювання пов'язані 3 діяльністю органів виконавчої влади, охоплюють суспільні відносини управлінського характеру, що складаються у цій сфері державної діяльності 3 керівництва економікою, соціальною сферою і культурою, адміністративною діяльністю [8, с. 192]. Виходячи з наведеного співвідношення державного управління та адміністративно-правового регулювання, виділяють два підходи до визначення державного управління в галузі мисливського господарства та полювання:

1) особливий інститут фауністичного права, який включає в себе сукупність правових норм, що визначають права та обов'язки державних, самоврядних, громадських органів 3 організації, раціонального використання, відтворення тваринного світу та забезпечення його охорони;

2) діяльність відповідних органів державного управління стосовно диких тварин та птахів [9].

Оскільки мисливство є чи не найпоширенішим різновидом спеціального використання тваринного світу - дикої фауни, варто зупинитись на оглядовому дослідженні адміністративно-правового регулювання суспільних відносин у галузі охорони, використання і відтворення тваринного світу. В одній зі своїх праць I.А. Городецька доходить висновку, що сутність адміністративноправового регулювання суспільних відносин у галузі охорони, використання і відтворення тваринного світу виявляється крізь призму співвідношення потреб (інтересів) суб'єктів цих відносин (які можливо задовільнити завдяки інструментарію адміністративноправового регулювання) і мети адміністративно-правового регулювання, за умови кореляції останньої із загальною метою пра- 
вового регулювання вказаних суспільних відносин [10, с. 65].

Серед науковців склався загальний підхід до розуміння принципів як керівних положень, теоретичних ідей, що відображають об'єктивні закономірності та закріплені у праві. Проте окремі науковці вважають, що принцип - це специфічне поняття, в якому міститься не стільки закономірність, відносини, взаємозв'язок, скільки наше знання про них [11, с. 262]. Принципи характеризуються двома ознаками: а) належністю до пізнаних наукою і практикою позитивних закономірностей; б) зафіксованістю в суспільній свідомості (відповідних поняттях) [12 с. 180]. Принципи адміністративно-правового регулювання в галузі мисливського господарства та полювання традиційно можна поділити на дві групи: загальні та спеціальні.

Загальні принципи стосуються здійснення адміністративно-правового регулювання в цілому. Серед них можна виділити приниип верховенства права, що закріплений в статті 8 Конституції України. Так, Конституція України має найвищу юридичну силу, закони та інші нормативно-правові акти приймаються на основі Конституції України і повинні відповідати їй. Тобто адміністративно-правове регулювання здійснення мисливського господарства та полювання повинне здійснюватися з урахуванням юридичної сили нормативно-правових актів.

Принцип законності адміністративноправового регулювання пов'язаний 3 тим, що суб'єкти адміністративно-правового регулювання здійснюють свої повноваження в межах та у спосіб, що встановлені Конституцією та законами України.

Приниип пріоритету прав і свобод людини $i$ громадянина зумовлений положеннями ст. 3 Конституції України, а саме: «Людина, іiї життя і здоров'я, честь і гідність, недоторканність і безпека визнаються в Україні найвищою соціальною цінністю. Права і свободи людини та їх гарантії визначають зміст і спрямованість діяльності держави. Держава відповідає перед людиною за свою діяльність. Утвердження і забезпечення прав і свобод людини є головним обов'язком держави». 3 огляду на такі положення, діяльність держави, в тому числі і державне управління, спрямовані насамперед на задоволення потреб людини і громадянина у певній галузі, тобто діяльність держави покликана створити відповідні умови для реалізації прав громадян [13, с. 117].

Приниип рівності громадян перед законом також базується на положеннях Конституції України: усі люди є вільні і рівні у своїй гідності та правах. Права і свободи людини
$€$ невідчужуваними та непорушними. Не може бути привілеїв чи обмежень за ознаками раси, кольору шкіри, політичних, релігійних та інших переконань, статі, етнічного та соціального походження, майнового стану, місця проживання, за мовними або іншими ознаками.

Серед спеціальних принципів адміністративно-правового регулювання мисливського господарства та полювання слід виділити приниип науково-обгрунтованих підходів до формування мисливської політики в Украïнi. Так, 27 листопада 2018 року Окружний адміністративний суд Києва скасував заборону полювання на лося і його внесення до Червоної книги. Таким чином, суд визнав протиправним торішній наказ Міністерства екології та природних ресурсів, яким тварину і було внесено до Червоної книги. На сайті суду сказано, що міністерство у своєму рішенні не навело «жодного наукового обгрунтування необхідності занесення тварини до Червоної книги України та не зазначило чітких даних щодо чисельності популяції та її динаміки» [14].

Водночас існуе приниип врахування екологічної доступності мисливських тварин, що перебувають у стані природної волі або утримуються в напіввільних умовах у межах мисливських угідь та які виступають об’єктом здійснення полювання. Так, зокрема наказом Міністерства охорони навколишнього природного середовища України від 17.06.2009 № 313 затверджено Перелік видів тварин, що заносяться до Червоної книги України (тваринний світ), тим самим встановлено перелік об'єктів тваринного світу полювання на яких заборонено законодавцем.

Приниипом збереження мисливськоі фауни пронизана вся політика держави щодо адміністративно-правового регулювання мисливського господарства та полювання. Так, для прикладу, наказ Державного комітету лісового господарства України № 56 від 21.06.2001 «Про затвердження Порядку проведення упорядкування мисливських угідь» містить орієнтовану шкалу визначення ступеня поточного впливу різноманітних чинників на мисливську фауну. Якщо погіршення середнього бонітету виникає з вини користувача мисливських угідь і призводить до зменшення середнього бонітету на один клас (не ведеться боротьба з браконьєрством, підгодівля диких тварин у разі несприятливих кліматичних умов, незадовільний стан формування популяцій диких тварин за віковою та статевою структурою, недостатня кількість штучно створених кормових та захисних ремізів, штучних водопоїв, біотехнічних споруд, незадовільна боротьба 
3 хижаками, не проводяться санітарні профілактичні заходи тощо), то користувачам мисливських угідь зменшуються на $10 \%$ установлені норми (відсотки) вилучення річного приросту диких тварин [15]. Аналізуючи положення вказаного Порядку, можна дійти висновку про існування ще одного принципу адміністративно-правового регулювання, а саме територіальності здійснення державного регулювання. Так, зокрема мисливські угіддя Карпатського регіону України розміщені на території чотирьох областей і становлять єдину природну систему зі своїми особливостями. Тому в управлінні ними слід координувати й узгоджувати діяльність органів зазначених адміністративно-територіальних одиниць (областей).

Принщип збереження біорізноманіття тваринного і рослинного світу мисливських угідь випливає з вимог «Конвенції про охорону біологічного різноманіття», до якої Україна приєдналася ще в 1994 р. Так, відповідно до положень вказаної Конвенції кожна Договірна Сторона повинна 1) розробити національні стратегії, плани чи програми збереження і сталого використання біологічного різноманіття або адаптувати 3 цією метою існуючі стратегії, плани або програми, які відображають, зокрема, викладені у Конвенції заходи, що стосуються відповідної Договірної Сторони; 2) передбачити, наскільки це можливо і доцільно, заходи щодо збереження і сталого використання біологічного різноманіття у відповідних секторальних або міжсекторальних планах, програмах і політиці [16].

Приниип рівності мисливських угідь усіх форм власності як об'єктів користування випливає з положень ст. 3 Закону України «Про мисливське господарство та полювання». Так, мисливські тварини, що перебувають у стані природної волі в межах території України, є об'єктом права власності Українського народу. Від імені Українського народу права власника мисливських тварин здійснюють органи державної влади та органи місцевого самоврядування в межах, визначених Конституцією України [17]. Законом встановлений єдиний порядок надання мисливських угідь у користування незалежно від форми власності, єдині права та обов'язки, гарантії та захист користувачів таких угідь.

Важливим для забезпечення охорони й відтворення природних ресурсів є приниип ефективного використання мисливських угідъ. Впровадження даного принципу розпочиналось ще у 1996 році, коли Міністерство лісового господарства відповідно до Постанови Кабінету Міністрів України від 20.07.1996 № 780 «Про затвердження
Положення про мисливське господарство та порядок здійснення полювання» звернулося до начальників обласних управлінь лісового господарства 3 листом від 24.10.1996 № 03-06/2250 [18], рекомендуючи 3 метою ефективного ведення мисливського господарства чітко встановити господаря конкретних мисливських угідь і виключити із цієї схеми обласні ради товариства УТМР, а таке право закріпити виключно за районними організаціями, бо за Статутом УТМР обласним радам не надано повноважень здійснювати ведення мисливського господарства, оскільки вони є керівним органом у період між конференціями обласної організації товариства. Держкомлісгосп також намагався запровадити принципи конкурентності надання мисливських угідь у користування, який і досі у законодавстві України не відображено й після його реорганізації у Державне агентство лісових ресурсів України. Приклад позитивного впровадження принципу ефективного користування мисливськими угіддями наводить у своїй праці Н. Березіна [19]. Так, з ініціативи Івано-Франківської обласної державної адміністрації було затверджено «Положення про попередній відбір претендентів для надання мисливських угідь на конкурентних засадах» [20] і створено компетентну комісію. Відповідно до п. 4. цього Положення претенденти подають заявки в обласне управління лісового та мисливського господарства, а п. 6 визначено вимоги до претендента на отримання мисливських угідь у користування. Зокрема, у бізнес-плані розвитку мисливського господарства мають бути відображені: 1) обсяг вкладення коштів; 2) чисельність єгерської служби, середня заробітна плата, освітній рівень її співробітників; 3) матеріально-технічне забезпечення (автотранспорт, зброя, засоби зв'язку та інше); 4) зобов'язання щодо обсягів біотехнічних заходів (годівниці, солонці, корми, кормові поля, вольєри, тощо); 5) облаштування мисливських доріг і стежок; 6) зобов'язання щодо підтримки місцевих громад; 7) зобов'язання щодо відшкодування збитків, завданих дикими тваринами сільському і лісовому господарству. Лише претендент, який отримав рекомендації комісії, має право на збір відповідних погоджень для сесії обласної ради (згідно з п. 9 цього Положення).

Варто виділити також приниип збалансованого розвитку мисливського господарства як один із принципів адміністративно-правового регулювання відповідної галузі, що передбачає постійне вдосконалення ведення мисливського господарства 3 огляду на потреби раціонального користування природними ресурсами. 15 листопада 2017 року 
на засіданні Кабінету Міністрів України схвалена «Стратегія реформування лісового та мисливського господарства України на період до 2022 року», в якій досліджені проблеми вказаних галузей, а також їх розвиток та загальний план реформування на наступні роки. Однак база даних «Законодавство України» досі не містить повного тексу затвердженої стратегії, на дату звернення ми могли ознайомитися лише з Проектом вказаної Стратегії.

О.О. Томин виділяє, серед інших, приниип розподілу господарсько-експлуатачійних та контрольно-наглядових функиій спеціальних органів державного управління у галузі мисливського господарства та полювання. Цей принцип полягає у тому, що один і той же орган державного управління не може виконувати контрольно-наглядові функції управління охороною і використання мисливських ресурсів і одночасно функції з господарського використання відповідних ресурсів. Пояснюе науковець це тим, що орган який здійснюе господарську діяльність, не буде ефективно здійснювати контроль за тією ж діяльністю, тобто сам себе контролювати. Така ситуація, на думку О.О. Томина, є абсурдною. Саме тому метою даного принципу $є$ забезпечення об'єктивності екологічного контролю і нагляду та ефективність дії права в галузі охорони тваринного світу [9, с. 203]. При цьому науковець не конкретизує та не описує згадувані повноваження, а також не називає органи, яким вони належать.

Проте нині законодавець не дотримується правил чіткого розподілення функцій між центральними органами влади. Так, відповідно до Закону України «Про центральні органи виконавчої влади» [21] центральні органи виконавчої влади утворюються для виконання окремих функцій 3 реалізації державної політики як служби, агентства, інспекції. При цьому критерієм віднесення центрального органу виконавчої влади до агентства, служби чи інспекції є більшість функцій, на виконання яких утворений такий орган. Вживаючи словосполучення «більшість функцій», законодавець таким чином допускає поєднання контрольнонаглядових функцій з іншими, в тому числі господарського-експлуатаційними. Прикладом цього є Положення про Державне агентство лісових ресурсів України [22], в якому до повноважень вказаного центрального органу виконавчої влади належать нарівні з контрольно-наглядовими й інші.

Таким чином, можемо стверджувати, що натепер приниип розподілу господарськоексплуатачійних та контрольно-наглядових функцій спеціальних органів державного управління у галузі мисливського господарства та полювання не притаманний адміністративно-правовому регулюванню в галузі мисливського господарства та полювання.

І.Г. Гуль, досліджуючи теоретико-методологічні основи ціноутворення на продукцію та послуги мисливського господарства, виділяє такі принципи цінової політики і ціноутворення в мисливському господарстві: 1) принцип спрямування цінової політики на досягнення максимальної величини економічного, екологічного та соціального ефектів від ведення мисливського господарства; 2) принцип гнучкості цінової політики і ціноутворення в мисливському господарстві; 3) принцип державної підтримки формування цінової політики в мисливському господарстві; 4) принцип пріоритетності стимулюючої функції ціни; 5) принцип урахування в ціні екологічних витрат [23].

В еколого-правовій літературі функції адміністративно-правового регулювання у сфері природокористування і природоохоронної діяльності визначаються як види діяльності державних органів виконавчої влади, місцевого самоврядування та громадських організацій із забезпечення організації раціонального використання природних ресурсів, їх відтворення та захисту і охорони навколишнього середовища [24, с. 38]; основні напрями діяльності відповідних суб'єктів щодо організації охорони довкілля [25, с. 86].

Головним напрямом діяльності держави в нових сучасних умовах стає створення сприятливих правових і економічних умов для перетворень у різних сферах, у тому числі й у сфері земельних відносин, що й позначається терміном «державне регулювання», що, на відміну від управління, передбачає дещо іншу стратегію - не надання впливу для забезпечення виконання певних рішень, а створення належних умов для ефективного функціонування відповідної сфери. Тож слід зазначити, що самий зміст діяльності держави як універсального суб'єкта управління в цілому залишається незмінним. Зміни, що відбуваються, стосуються лише ступеня та характеру втручання - переважаючою формою впливу стає державне регулювання, а зміст державного впливу становлять функції прогнозування і планування, організаційно-реєстраційна функція, а також функція контролю [26, с. 169].

Функції державного управління у сучасній науці розрізняють за органами, що їх здійснюють, за місцем і значенням в управлінському процесі, за юридичними наслідками та ін. [27, с. 87].

На нашу думку, функції адміністративно-правового регулювання в галузі 
мисливського господарства та полювання варто поділити на загальні та спеціальні. Так, загальними функціями, які притаманні всім системам управління, є планування, координація, організація, регулювання, контроль. Виділяючи спеціальні функції. звернемось до функцій конкретних суб'єктів, що здійснюють адміністративноправове регулювання в галузі мисливського господарства та полювання. Так, Положенням про державне агентство лісових ресурсів [22] передбачені такі спеціальні функції відповідного органу: нормотворча, моніторингу грунтів, нормування, ведення державного кадастру мисливських тварин, обліку чисельності і добування мисливських тварин, дозвільна, екологічної паспортизації, розгляду справ про адміністративні правопорушення, забезпечення реалізації соціальної політики. Функцію програмування здійснює Міністерство аграрної політики відповідно до Положення про Міністерство аграрної політики та продовольства України [28].

\section{Висновки}

Забезпечення охорони навколишнього природного середовища та сприяння сталому природокористуванню стають одними з головних функцій держави. Основу правового регулювання будь-якої сфери людської діяльності становлять правові принципи основні засади побудови самої системи адміністративно-правового регулювання тієї чи іншої сфери. Розроблення, юридичне закріплення та чітке виконання й дотримання принципів правового регулювання мисливського господарства та полювання є запорукою сталості, ефективності та раціональності досліджуваного виду природокористування. Впровадження принципів адміністративноправового регулювання в галузі мисливського господарства та полювання сприятиме організації та розвитку вказаних галузей, a їх дотримання позитивно впливатиме на відтворення та використання мисливських угідь та послуг (продукції) мисливського господарства та полювання, збереження різноманіття тваринного світу в межах мисливських угідь на території України.

\section{Список використаних джерел:}

1. Великий тлумачний словник сучасної української мови (з дод. і допов.) / ред. В. Т. Бусел. Київ : Ірпінь. ВТФ «Перун», 2005. 1728 с.

2. Кашанина Т.В. Соотношение централизованного и децентрализованного правового регулирования. Правоведение. 1991. № 4. С. 54-64.

3. Дюрягин И.Я. Право и управление. Москва : Юрид. лит, 1981. 168 с.
4. Явич Л.С. Проблемы правового регулирования советских общественных отношений. Москва : Госюриздат, 1961. 172 с.

5. Галунько В.В. Поняття та зміст адміністративно-правового регулювання. URL : http://www. law-property.in.ua. (дата звернення: 07.07.2019).

6. Шопіна I. M. Адміністративно-правове регулювання управління органами внутрішніх справ України : дис. ... доктора юрид. наук : 12.00.07. Київ, 2012. 514 с.

7. Пацурківський П.С. Інтегративний підхід в системі методів пізнання права. Науковий вісник Чернівецького університету. Серія «Правознавство». 2000. Вип. 75. С.10-18.

8. Адміністративне право України : підручник для юрид. вузів і фак. / Ю.П. Битяк, В.М. Гаращук, О.В. Дьяченко та ін. Київ, 2004. 401 с.

9. Томин О.О. Принципи державного управління в галузі мисливства та полювання в Україні. Украӥнські наукові записки. 2009. № 1 (29). C. 203-205.

10. Городецька I.A. Сутність адміністративноправового регулювання суспільних відносин у галузі охорони, використання і відтворення тваринного світу. Форум права. 2016. № 1. С. 60-66. URL: file:///C:/Users/PC/Downloads/FP index. htm 20161 12\%20(1).pdf (дата звернення: $07.0 \overline{7} .2019 \overline{)}$.

11. Атаманчук Г.В. Теория государственного управления: курс лекций. Москва : Юрид. лит., $2004.400 \mathrm{c}$

12. Державне управління : підручник : у 2-х т. / ред. кол.: Ю. В. Ковбасюк (голова), К. О. Ващенко (заст. голови), Ю. П. Сурмін (заст. голови) [та ін.]. Київ-Дніпропетровськ : НАДУ, 2012. Т. 1. С. 180.

13. Максіменцева Н. Співвідношення принципів адміністративного права та принципів державного управління. Підприємниитво господарство $i$ право. 2017. № 5. С. 115-118.

14. Рішення Окружного адміністративного суду міста Києва по адміністративній справі № $826 / 9432 / 17$. URL: http://oask.gov.ua/ node/3620 (дата звернення: 07.07.2019).

15. Про затвердження Порядку проведення упорядкування мисливських угідь : наказ Державного комітету лісового господарства України № 56 від 21.06.2001. URL: https:// zakon.rada.gov.ua/laws/show/z0771-01 (дата звернення: 07.07.2019).

16. Конвенція про охорону біологічного різноманіття ратифікована Законом № 257/94-ВР від 29.11.94 // База даних «Законодавство України». URL: https://zakon.rada.gov.ua/laws/ show/995_030 (дата звернення: 07.07.2019).

17. Про мисливське господарство та полювання : Закон України від 22.02.2000 № 1478-III // База даних «Законодавство України». URL: https://zakon.rada.gov.ua/laws/show/147814 (дата звернення: 07.07.2019).

18. Про затвердження Положення про мисливське господарство та порядок здійснення полювання : Постанова Кабінету Міністрів України від 20.07.1996 № 780. URL: http:// 
zakon3.rada.gov.ua/laws/show/780-96-\%D0\%BF (дата звернення: 07.07.2019).

19. Березіна Н. Правове регулювання відносин у сфері користування мисливськими угіддями: окремі аспекти й особливості суб'єктного складу. Підприємниитво, господарство і право. 2019. № 8. C. 89-93.

20.Положення про попередній відбір претендентів для надання мисливських угідь на конкурентних засадах : затверджено першим заступником голови Івано-Франківської облдержадміністрації 9 серпня 2011 року). Івано-Франківськ, 2011

21. Про центральні органи виконавчої влади : Закон України від 17.03.2011 № 3166-VI // База даних «Законодавство України. URL: https:// zakon.rada.gov.ua/laws/show/3166-17 (дата звернення: 07.07.2019)

22. Про Положення про Державне агентство лісових ресурсів України : Указ Президента України від 13.04.2011 № 458/2011 // База даних «Законодавство України». URL: https:// zakon.rada.gov.ua/laws/show/458/2011 (дата звернення: 07.07.2019)
23.Гуль І.Г. Теоретико-методологічні основи ціноутворення на продукцію та послуги мисливського господарства. URL: https:// essuir.sumdu.edu.ua/bitstream/123456789/11233/ 1/26.pdf (дата звернення: 07.07.2019).

24. Екологічне право України : підручник / за ред. А. П. Гетьмана, М. В. Шульги. Харків : Право, 2005. $384 \mathrm{c}$.

25. Кобецька Н. Р. Екологічне право України : навчальний посібник. Київ : Юрінком Інтер, 2007. $352 \mathrm{c}$.

26. Пахомов В.В. Адміністративно-правове регулювання земельних відносин в Україні: поняття, завдання та функції. Форум права. 2015. № 3. C. $167-172$.

27. Корнєєв Ю.В. Земельне право : навчальний посібник. Київ : Центр навчальної літератури, 2011. $248 \mathrm{c}$.

28. Про затвердження Положення про Міністерство аграрної політики та продовольства України : Постанова Кабінеті Міністрів від 25.11.2015 № 1119. URL: https://zakon.rada.gov.ua/ laws/show/1119-2015-\%D0\%BF (дата звернення: 07.07.2019).

The article deals with the administrative and legal regulation in the field of hunting and hunting. The author's approach to the classification of principles and functions of administrative and legal regulation in the research area is offered. It is emphasized that it is advisable to distinguish the following principles of pricing policy and pricing in the hunting industry: 1) the principle of directing the pricing policy to maximize the economic, environmental and social effects of hunting; 2) the principle of flexibility of pricing policy and pricing in hunting farms; 3) the principle of state support for pricing policy in the hunting economy; 4) the principle of priority of the price incentive function; 5) the principle of taking into account the cost of environmental costs. It is determined that the main direction of the state's activity in the new modern conditions is to create favorable legal and economic conditions for transformations in various spheres, including in the sphere of land relations, which is denoted by the term "state regulation", which, unlike management, envisages a slightly different strategy - not to influence the implementation of certain decisions, but to create the right conditions for the effective functioning of the respective sphere. It has been concluded that ensuring environmental protection and promoting sustainable use of nature are becoming one of the main functions of the state. Legal principles of any sphere of human activity are the basis of legal principles - the basic principles of construction of the system of administrative and legal regulation of this or that sphere. Development, legal fixing and clear implementation and adherence to the principles of legal regulation of hunting and hunting are the key to the sustainability, efficiency and rationality of the studied nature use. The implementation of the principles of administrative and legal regulation in the field of hunting and hunting will promote the organization and development of these industries, and their observance will positively affect the reproduction and use of hunting grounds and services (products) of hunting economy and hunting, conservation of the diversity of fauna within the hunting grounds in the territory of Ukraine.

Key words: hunting, hunting economy, principles, functions, administrative-legal regulation, state administration. 